\title{
Induction of stolon settlement in the scyphopolyps of Aurelia aurita (Cnidaria, Scyphozoa, Semaeostomeae) by glycolipids of marine bacteria
}

\author{
G. Schmahl \\ Lehrstuhl für Spezielle Zoologie und Parasitologie, Ruhr-Universität Bochum, \\ D-4630 Bochum 1, Federal Republic of Germany
}

\begin{abstract}
The settlement of pedal stolons of scyphopolyps of Aurelia aurita Lamarck could be induced by addition of a species of bacteria from the family Micrococcaceae. After treatment of the bacteria with several organic solvents a crude lipid extract free of bacteria could be obtained which was shown to be effective in inducing stolon settlement. Crude lipids extracted from the late logarithmic growth phase had an optimal effect on stolon attachment, in contrast to previously published experiments showing that all logarithmic phases of bacteria had the same level of effectiveness. After separation of the crude lipid extracts by thin layer chromatography and subsequent bioassay of the reeluated substances, acylgalactosidyldiglyceride and monogalactosidyldiglyceride were identified as the effective substances. Monogalactosidyldiglyceride was only found in bacteria from the medium logarithmic growth phase, whereas the former was found at all stages. The effectiveness of acylgalactosidyldiglyceride was independent of the growth phase of the extracted bacteria.
\end{abstract}

\section{INTRODUCTION}

A previous investigation (Schmahl,1984) showed that the settlement of the stolons of Aurelia aurita is bacterially induced. From a substrate capable of inducing settlement, several species of bacteria were isolated, one of which was shown to be especially effective. The settlement reaction could only be evoked on direct contact of the stolons with the bacteria and the bacteria were only effective during their phase of logarithmic growth. Bacterially induced settlement has been investigated in some marine coelenterate larvae and in animals belonging to different phyla.

Swimming buds and planula larvae of Cassiopea andromeda (Scyphozoa) were induced to settle and metamorphose by a factor emanating into the culture medium from a species of Vibrio during growth (Neumann, 1976; Hofmann et al., 1978; Neumann, 1979; Neumann et al., 1980). In the planula larvae of Hydractinia echinata (Hydrozoa) a pheromone-like lipid which is excreted by various species of bacteria was effective in inducing metamorphosis (Müller, 1969; 1973a). Herrmann (1976) assumed that electrokinetic processes on bacterial surfaces were responsible for the initiation of metamorphosis in the larvae of Phoronis muelleri (Phoronida).

The aim of the present study described here was to isolate and characterize the bacterial product that induces settlement of stolons in Aurelia aurita. 


\section{MATERIALS AND METHODS}

A n i mals. The scyphopolyps of Aurelia aurita were from a clone of planulae from a medusa of the Mutsu Bay in the North of the Hondo island (Japan).

The scyphistomae were kept in 4 l glass tanks at $19.5 \pm 0.5^{\circ} \mathrm{C}$ on a $16: 8 \mathrm{~h}$ light: dark cycle in seawater ( $30 \%$ salinity). The animals were fed nauplii of Artemia salina twice weekly. The culture medium was changed 3-5 h after feeding.

For the experiments, seawater containing antibiotics was used (100 mg penicillin G-potassium salt (Serva), $129 \mathrm{mg}$ streptomycin-sulfate (Serva) $\times 1000 \mathrm{ml}^{-1}$ pasteurized seawater). Scyphistomae without buds and stolons were chosen. The basal fifth of the animals was dissected a day before the beginning of the experiment with an ophthalmological scalpel. Thereafter, the animals were kept in $150 \mathrm{ml}$ Boveri dishes in seawater containing antibiotics. Within $24 \mathrm{~h}$ after the operation each animal normally produced one stolon, so that animals with stolons of the same age were available for the experiments.

Settlement of the stolon tips was considered to have taken place when the tip could not be removed from the substrate without tearing the shaft of the stolon when probed with a sterilized needle.

$\mathrm{St}$ o c k culture of bacteria. Bacteria were maintained in either agar cultures ( $40 \mathrm{~g}$ tryptic soy agar, Difco; $5 \mathrm{~g}$ agar, Merck; $25 \mathrm{~g} \mathrm{NaCl} \times 1000 \mathrm{ml}^{-1}$ distilled water), or liquid culture $\left(200 \mathrm{mg}\right.$ bacto-pepton, Difco; $1000 \mathrm{mg} \mathrm{D}(+)$-Glucose $\times 1000 \mathrm{ml}^{-1}$ seawater).

The preparations were autoclaved for $30 \mathrm{~min}$ at 0.5 bars.

Harvesting of bacterial lipids. The starting material for harvesting lipids were samples of $2000 \mathrm{ml}$ in volume. In order to start with the same amount of bacteria per volume unit, samples from different growth phases were adjusted to the same extinction value of $\mathrm{E}_{460}: 0.250$. In this manner, prepared samples of liquid cultures were centrifuged to get bacterial pellets for preparation of lipids.

The lipids were extracted according to the method of Bligh \& Dyer (1959). The extraction of bacteria from the three phases of logarithmic growth chosen $\left(E_{460}: 0.150\right.$, $\mathrm{E}_{460}: 0.250, \mathrm{E}_{460}: 0.690$ ) yielded almost the same amount of total lipid (1.98-2.04 mg) each of which was dissolved in $1 \mathrm{ml}$ of chloroform. BHT (2.6-Dis.-tert.-butyl-4 methyl-phenol, Fluka AG) was added to the solvents as an anti-oxidant (Dodge, 1966).

For the bio-assays the crude lipid equivalents were always emptied into the dish in a fashion so as to allow the bottom to be covered by a lipid film after the solvent had evaporated. For very small volume equivalents (e.g. $50 \mu \mathrm{l}, 175 \mu \mathrm{l}$ ), this was achieved by adding $2 \mathrm{ml}$ of chloroform so that the bottom of the Boveri dish was just covered. For larger volume equivalents, evaporation was achieved in steps, or the volumes of the samples were reduced under vacuum conditions before they were emptied into the Boveri dishes.

Th in layer chrom a tography. The extract of the crude lipid was separated by means of commercially fabricated plates (Silicic gel 60 , layer 0.5 resp. $0.25 \mathrm{~mm}$, Merck). They were activated before use for $3 \mathrm{~h}$ at $110^{\circ} \mathrm{C}$. The lipids were made visible with iodine vapour. The identification of the lipid fractions was achieved by cochromatography of reference substances and by demonstrating the presence of certain classes of substances such as: 
Phosphoric acid esters. Ammoniummolybdate-perchlorine acid was used as a tracer. After spraying the plates they were heated at $120^{\circ} \mathrm{C}$ for $20-30 \mathrm{~min}$. Phospholipids were stained blue.

Amino-groups. Amino-groups were traced with $0.1 \%$ Ninhydrin-spraying reagent (Merck). After $5-10 \mathrm{~min}$ at $105^{\circ} \mathrm{C}$, purple spots signified a positive reaction.

Gly colipids. Glycolipids were traced by periodate-Schiff reagent (Shaw, 1968).

Glycosides in glykolipids. After a mild, acid hydrolysis, aliquots of the hydrolysate were chromatographed on Na-acetate-buffered cellulose plates $(0.1 \mathrm{~mm}$ thickness, Merck) in ethylacetate/pyridine/water $(\mathrm{v}: \mathrm{v}=2: 1: 2)$ at room temperature. The qualitative demonstration of glycosides was achieved by spraying the plates with silver nitrate solution, $0.5 \mathrm{n} \mathrm{NaOH}$ in ethanol and $5 \%$ aqueous Nathiosulfate solution. Glycosides were recognized as dark brown spots on a light brown background.

Statistics. For comparison between pairs, the U-test of Mann \& Whitney was used. For comparison between groups the Chi-square test was used. The level of significance for all calculations was considered to be the $1 \%$ limit.

\section{RESULTS}

A number of different ways of treating samples of bacteria to obtain a substance which induced stolon attachment were tested but proved to be unsuccessful. Among these were dialyses, UV-irradiation, and heat treatment. The only successful method was extraction with organic solvents. The effective substance was located in the lipophilous phase after separation, while the supernatant of the hydrophilous phase had no effect on stolon attachment.

For the experiment described below, the bacterial lipids were extracted and their biological effectiveness was tested. The amount of crude extract tested was the yield of the bacterial sediment in a $50 \mathrm{ml}$ sample (constant extinction value $\mathrm{E}_{460}: 0.250$ ).

The effectiveness of the lipid extracts depends upon the phase of bacterial growth as follows: Crude lipid extracts from bacteria of the late logarithmic growth phase resulted in the highest numbers of settled polyps. Extracts from bacteria in early and medium logphase were significantly less effective (Table 1).

Dose effect of crude lipid extract. In order to examine the question of whether a dose-effect relationship exists between the number of settled stolons and the volume of

Table 1. Aurelia aurita. Stolon settlement on addition of extracted entire bacterial lipids

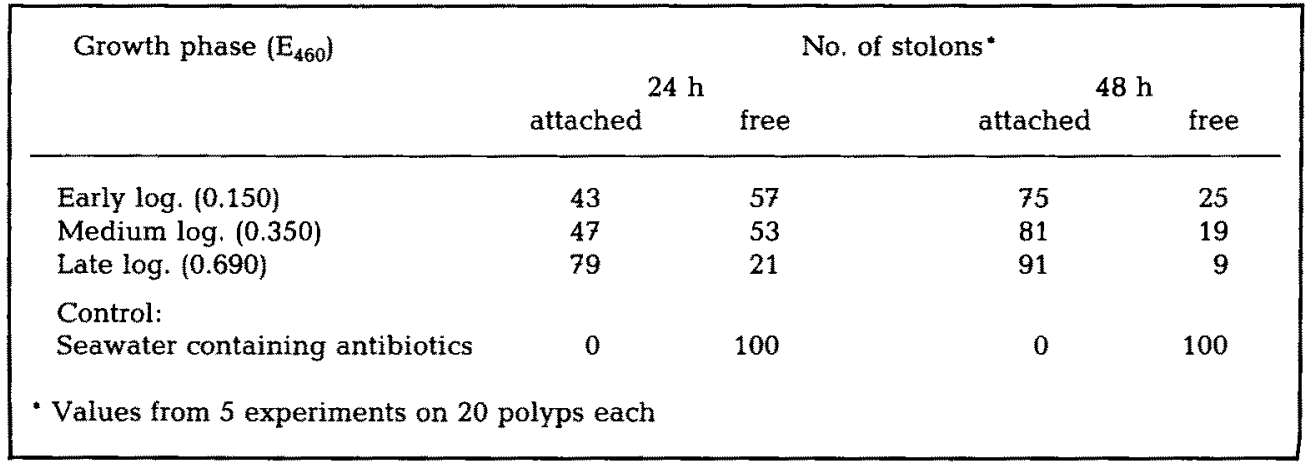


G. Schmahl

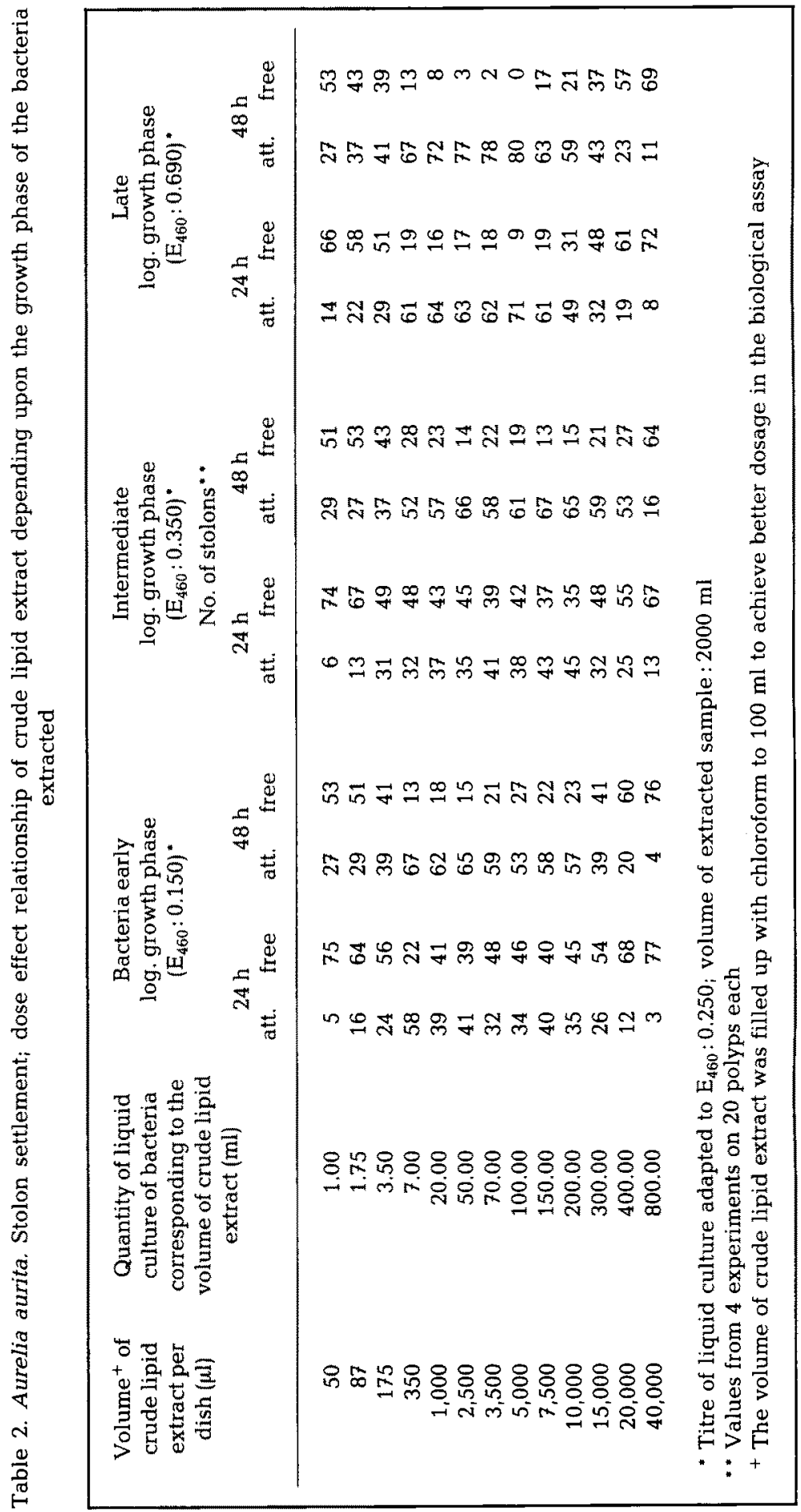


crude lipid applied, different concentrations of crude lipid were added to scyphistomae (Table 2).

Crude lipid extract from $1 \mathrm{ml}$ of bacterial suspension in all 3 stages of the logarithmic growth phase resulted in no significant increase of stolon settlement as compared to controls in sterile seawater. However, when the dose of crude lipid was raised to equivalents of $1.75,3.5 \mathrm{ml}$ bacterial suspension, the number of settled stolons increased. Equivalents between 7 and $200 \mathrm{ml}$ (early and medium log. phase) also showed an optimum range of stolon settlement. Further increases above $7 \mathrm{ml}$, but less than $150 \mathrm{ml}$, did not result in a significant increase in the number of settled polyps.

Still higher doses of bacterial extracts from the early logarithmic growth phase $\left(\mathrm{E}_{460}: 0.150\right)$ and from the late logarithmic phase led to a decrease in stolon settlement. In these latter experiments the animals showed signs of damage: some were attached to the bottom by their hypostomes, and some had shortened tentacles, and some were permanently contracted.

In all tests above, an increase in stolon settlement was noted after $48 \mathrm{~h}$.

On comparing the effectiveness of lipid extracts from various bacterial growth phases within the range of the optimum values for attachment, one can make the following generalizations:

(1) Crude lipid extracts from bacteria in the late logarithmic phase lead to the highest percentages of settlement.

(2) Extracts from bacteria of the early and medium logarithmic phase are significantly less effective, and they do not differ from one another.

Thin layer chromatography of lipid extract: The crude lipid extract contains phospholipids and glycolipids among other lipids. The phospho- and glycolipids were identified by comparing them to the Rf values of standard preparations that had been chromatographed simultaneously and by the reactions of the different substances to various reagents. The crude lipid extracts were chromatographed in five different solvent systems in order to warrant a reliable identification of the individual fractions.

Table 3. Micrococcus sp. Identification of phospho - and glycolipids by thin layer chromatography

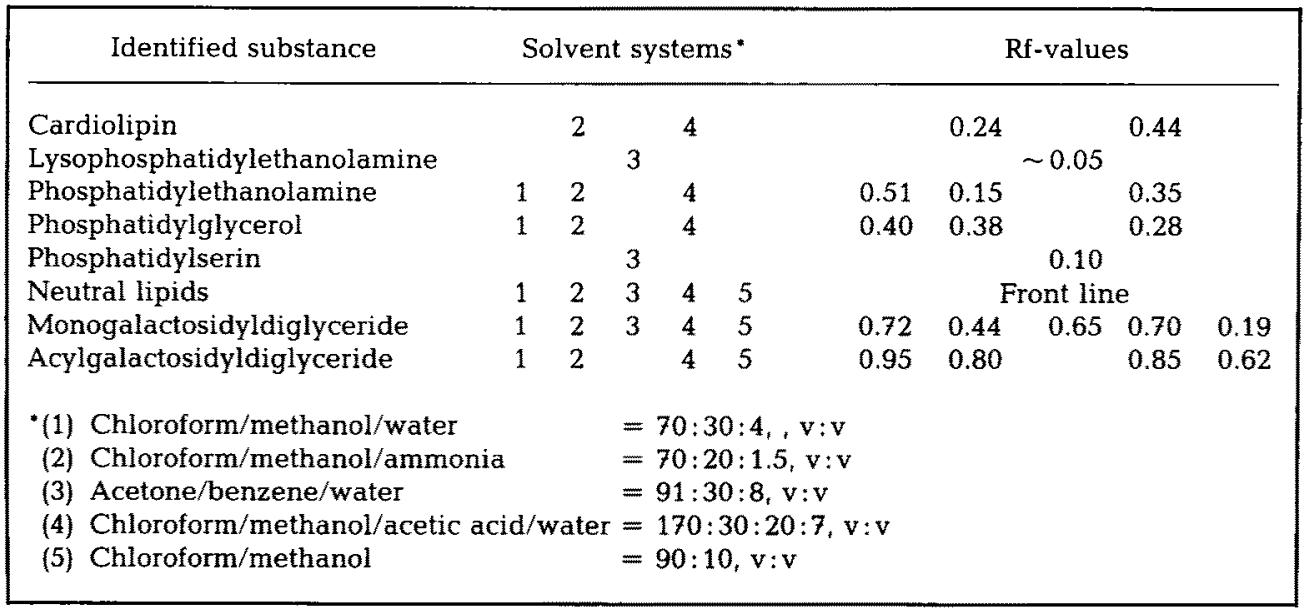


Table 3 lists the substances that could be identified by the techniques mentioned above.

After the chromatographic separation the fractions were removed from the plates and the lipid bands reeluated with chloroform-methanol. Defined volumes of the reeluates were tested in bio-assays after the solvent had been evaporated off. The

Table 4. Aurelia aurita. Stolon settlement; biological assays with reeluated fractions from chromatograms

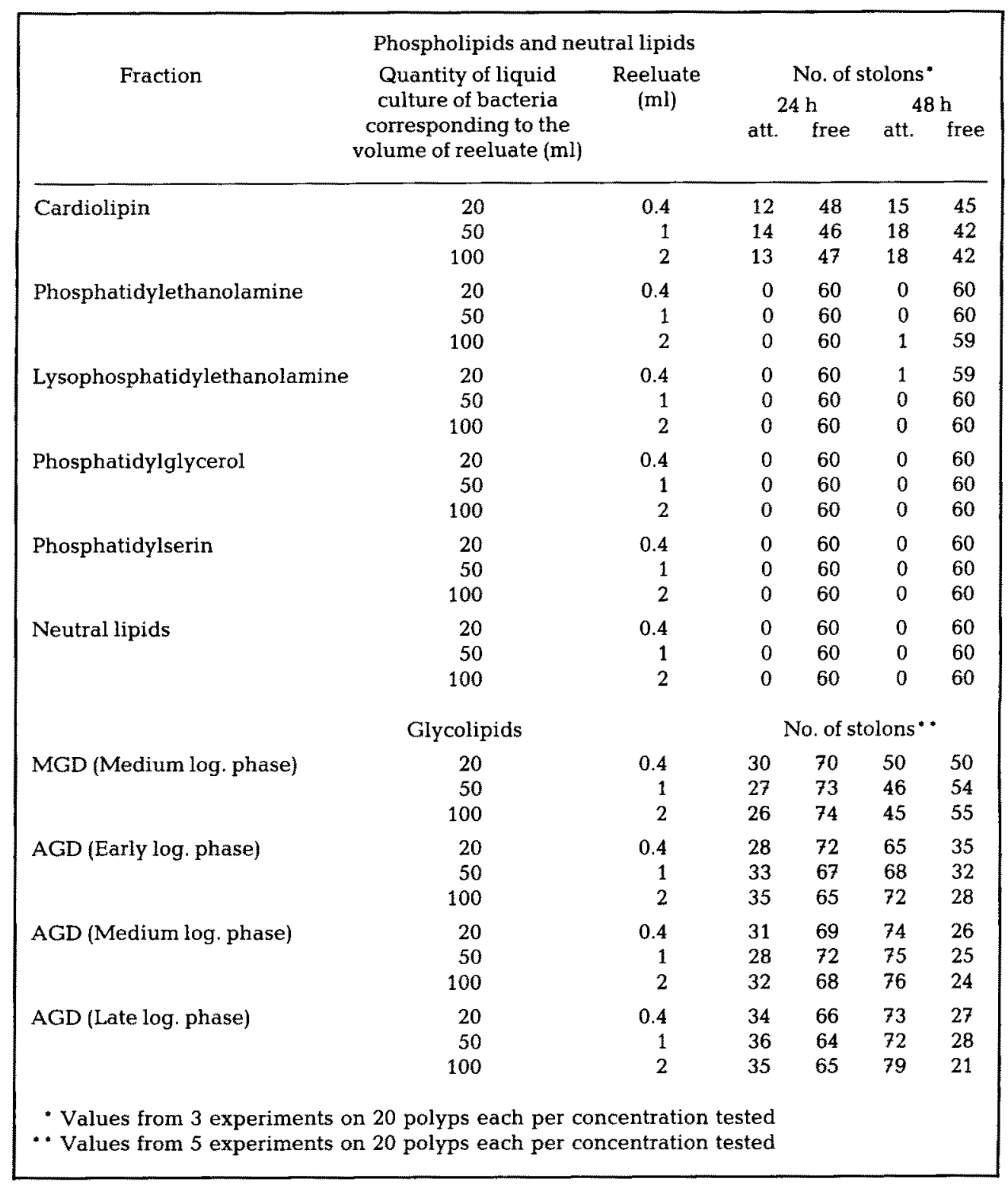


number of settled polyps was counted after $24 \mathrm{~h}$ and after $48 \mathrm{~h}$. The results are shown in Table 4.

A positive effect on stolon settlement was exerted by acylgalactosidyldiglyceride (AGD) and monogalactodidyldiglyceride (MGD). Stolon settlement was observed only occasionally after adding cardiolipin. The remaining lipids did not initiate stolon settlement. The addition of lysophosphatylethanolamine resulted in moderate damage of the scyphopolyps. After addition of MGD, only a slight increase in the number of settled polyps was noted after $48 \mathrm{~h}$ in comparison to the rate of settlement after $24 \mathrm{~h}$. On the other hand, in dishes containing AGD the number of settled animals after $48 \mathrm{~h}$ was twice as high as after $24 \mathrm{~h}$. As measured by the rate of settlement after $48 \mathrm{~h}$, acylgalactosidyldiglyceride had optimal effectiveness. In the settled animals, a distinct perisarc layer was seen without exception at the end plates of the stolons. This was an unequivocal sign for very strong contact between the stolon tip and the substrate.

Phospholipids and neutral lipids originating from crude bacterial lipid extract from bacteria in the late logarithmic growth phase, and glycolipids from bacteria of all 3 stages of logarithmic growth were tested for ability to induce stolon attachment.

In the Boveri dishes containing phospholipids and neutral lipids no dose-effect relationship was found for the concentrations used. Not one of the concentrations had any effect. The ability of glycolipid fractions to induce stolon attachment was also independent of the bacterial growth phase; however, these fractions induced attachment of stolons between 20 and $100 \mathrm{ml}$ of extracted bacteria (Table 4).

Subsequently, reeluates of effective substances were combined in different volumes and tested. The proportions of the lipids tested were always the same. These experiments were done in order to test whether the rate of stolon settlement would be different when several effective substances were added in comparison to experiments in which only one effective substance was used. The quantities of substances tested were equivalent to bacteria from 10,20,25, 50 and $100 \mathrm{ml}$ of liquid culture (liquid samples adjusted to $\mathrm{E}_{460}: 0.250$ for all 3 stages of logarithmic growth phase). According to their presence in bacteria from 3 stages of logarithmic growth the substances were combined as follows:

$\begin{array}{ll}\text { AGD + MGD } & \text { medium log. phase } \\ \text { AGD + MGD, Cardiolipin } & \text { medium log. phase } \\ \text { MGD } & \text { medium log. phase } \\ \text { AGD } & \text { early log. phase } \\ \text { AGD } & \text { medium log. phase } \\ \text { AGD } & \text { late log. phase }\end{array}$

For every combination of lipids five dishes were filled with an identical volume for each concentration. Controls were monitored 24,36 and $48 \mathrm{~h}$ after the onset of the experiment (Table 5).

The combined addition of MGD and AGD both from medium logarithmic growth phase resulted in only a slight increase in the number of settled stolons after $24 \mathrm{~h}$ as compared to experiments with only one glycolipid (MGD or AGD, both from medium logarithmic growth phase). After 36 and $48 \mathrm{~h}$ the combination of both glycolipids was found to be more effective than the addition of MGD on its own, while a clear difference from tests with AGD was not found.

Tests that contained AGD and cardiolipin led to a significantly higher rate of stolon 


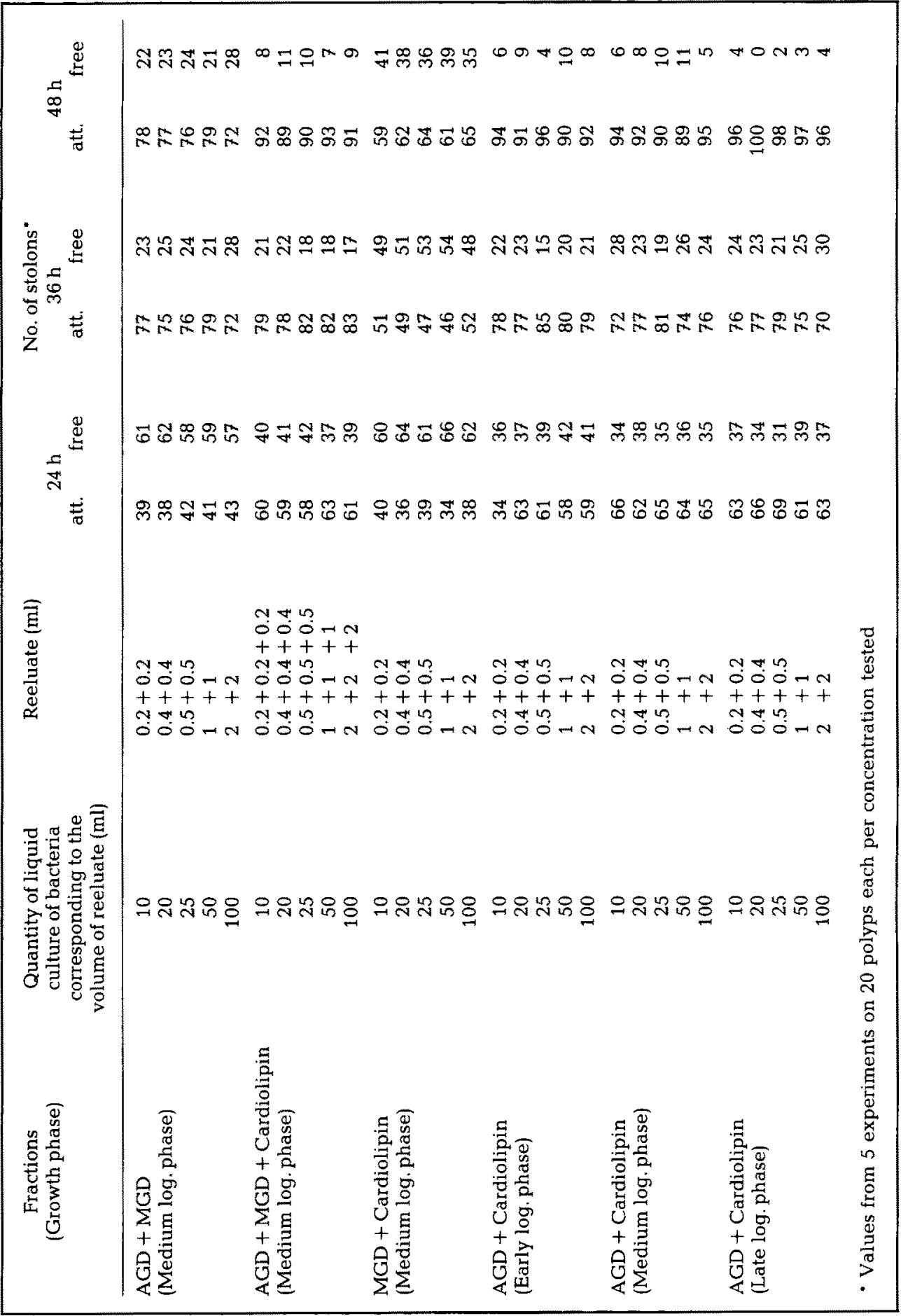


settlement in comparison to the experiments in which MGD was used on its own. An unequivocally higher rate of stolon settlement was found in combined set-ups after $24 \mathrm{~h}$ and $48 \mathrm{~h}$, as compared to those containing only AGD. After $36 \mathrm{~h}$, significant differences were found.

AGD, MGD (medium logarithmic phase)/AGD, MGD and cardiolipin (medium logarithmic phase):

Addition of cardiolipin resulted in an increased rate of stolon settlement when combined with MGD and AGD after $24 \mathrm{~h}$ as compared with tests not containing cardiolipin. The rates after $36 \mathrm{~h}$, however, do not differ significantly from those of assays not containing cardiolipin. After $48 \mathrm{~h}$, a significantly increased rate of stolon settlement was found in tests containing cardiolipin in comparison to tests without cardiolipin.

MGD, AGD and cardiolipin (medium logarithmic growth phase)/MGD and cardiolipin (medium logarithmic growth phase):

The addition of AGD to MGD and cardiolipin increased the effectiveness on initiation of stolon settlement compared to MGD and cardiolipin alone.

AGD and cardiolipin (early, medium and late logarithmic growth phase):

The origin of the AGD and the cardiolipin in relation to the growth phase of the bacteria that was extracted did not play a role in the effectiveness of this combination. No significant differences in the numbers of settled stolons were found.

MGD and cardiolipin (medium logarithmic growth phase)/AGD and cardiolipin (medium logarithmic growth phase):

A comparison of the effectiveness of these two combinations showed that AGD had a stronger effect than MGD at any time of sampling.

AGD, MGD and cardiolipin (medium logarithmic growth phase, AGD and cardiolipin (medium logarithmic growth phase):

Addition of MGD to the combination of and cardiolipin led to no further enhancement of stolon settlement.

A dose-effect relationship was not found in any of the combinatory experiments.

Only in tests containing AGD and cardiolipin was settlement of more than $50 \%$ of the animals observed as early as after $24 \mathrm{~h}$. It seems noteworthy that the crude lipid extract of bacteria from the medium logarithmic growth phase resulted in settlement of more than $50 \%$ of the polyps only some time later.

In further experiments the maximum effect combination (AGD and cardiolipin) was combined with another phospholipid each in order to test the influence of the additional lipid on stolon settlement. Not all possible combinations were tested. The maximum effect combination was combined in a single concentration (equivalent to $50 \mathrm{ml}$ bacterial suspension) with one of 3 arbitrarily chosen phospholipids. The substances were phosphatidylethanolamine, lysophosphatidylethanolamine, and phosphatidylserine. All isolated lipids came from bacteria of the late logarithmic growth phase. The effectiveness of AGD and cardiolipin does not appear to be changes after addition of phosphatidylethanolamine or phosphatidylserine. Lysophosphatidylethanolamine caused slight damage similar to that seen in the single-substance test, however this effect was not so serious at to impair stolon settlement. After addition of phosphatidylethanolamine, phosphatidylserine and lysophosphatidylethanolamine the results were comparable to the corresponding tests without these phospholipids. 


\section{DISCUSSION}

The settlement of the pedal stolons of Aurelia aurita depends upon a certain substance of bacterial origin. After isolation of various bacterial species, one species of the family Micrococcaceae proved expecially effective on the stolon settlement reaction.

In preliminary experiments, it was found that the effective principle possessed clearly lipophilous characteristics. The extracted bacterial lipids proved effective on the induction of stolon settlement. The crude lipid extract showed the highest effectiveness if it was harvested from bacteria in the late logarithmic growth phase.

When reeluated fractions of the chromatographed crude lipid were tested, a delay in settlement reaction was noted in comparison to the assays containing live bacteria. The delay of about $12 \mathrm{~h}$ was found in more than $50 \%$ of the animals. This retardation was observed for all doses tested. A possible explanation is that the effectiveness of the lipids was impaired by contact with the glass surface of the culture dish. Another possibility is a potential alteration of the effective substances during the procedure of preparation, for instance by dislocation of double-bonds in the unsaturated fatty acid.

After the preparation of crude lipid extracts by thin layer chromatography and subsequent bioassay of the reeluated fractions, two glycolipids were found to be effective on the induction of stolon settlement, when applied alone or in combination with the other. These substances were monogalactosidyldiglyceride and acylgalactosidyldiglyceride.

MGD was present only in extracts from bacteria of the medium logarithmic growth phase, while AGD was found in all extracts.

The initiation of settlement in pedal stolons is a problem that has not been dealt with yet. This is the reason why a direct comparison to settlement in other coelenterates is lacking. The finding that the settlement of these projections is induced by bacterial products in $A$. aurita, permits a limited comparison to the settlement behaviour of other marine invertebrates.

The first example for the initiation of a settlement reaction by exogeneous, bacterial factors was described for the planulae of Hydractinia echinata (Müller, 1969, 1973a, bi Müller \& Buchal, 1973). The inducing stimulus was identified as a short-lived phospholipid, phosphatidylethanolamine (Wittmann, 1977).

The metamorphosis of planulae and swimming buds of Cassiopea andromeda is likewise induced by bacteria (Neumann, 1976; Müller et al., 1976; Hofmann et al., 1978; Neumann, 1979). Unlike the bacteria which initiate metamorphosis in the planulae of $H$. echinata, their inductive activity does not reside in the bacterial surface but is shed into the medium during growth. The inductive principle was shown to be present in sterile filtrated substrate and was characterized in more detail. The effective principle was relatively heat-stable, the molecular weight could be shown to range somewhere between 1000 and 10000 daltons. From further investigations, Neumann (1980) drew the conclusion that the inducer was peptide-like, but at the same time contained heterogroups like lipid and glycosidic compenents.

A substrate-specific settlement and metamorphosis is found in the larvae of the hydrozoon Coryne uchidai; they only metamorphose on thalli of the alga Sargassum tortile. The inductive substance was isolated and shown to be $\delta$-tocotrienol (Nishihira, 1966; Kato et al., 1975). The participation of bacteria has not yet been excluded. 
Acknowledgements. I should like to thank Prof. Dr. D. K. Hofmann for reading the manuscript and for his helpful criticism. I am indepted to Dipl.-Biol. B. Brand for translating the paper, and wish to thank Dr. W. Fitt for reading the English manuscript.

\section{LITERATURE CITED}

Bligh, E. G. \& Dyer, W. J., 1959. A rapid method of total lipid extraction and purification. - Can. J. Biochem. Physiol. 37, 911-917.

Dodge, J. T., 1966. Autoxidation as a cause of altered lipid distribution in extracts from human red cells. - J. Lipid Res. 7, 387-395.

Herrmann, K., 1976. Untersuchungen über Morphologie, Physiologie und Okologie der Metamorphose von Phoronis muelleri (Phoronida). - Zool. Jb. (Anat. Ontogenie Tiere) 95, $354-426$.

Hofmann, D. K., Neumann, R. \& Henne, K, 1978. Strobilation, budding and initiation of scyphistoma morphogenesis in the Rhizostome Cassiopea andromeda (Cnidaria: Scyphozoa). - Mar. Biol. 47, 161-176.

Kato, T., Kumanireng, A. S., Ichinose, I, Kitahara, Y., Kakinuma, Y., Nishihira, M. \& Kato, M., 1975. Active components of Sargassum tortile effecting the settlement of swimming larvae of Coryne uchidai - Experientia 31, 433-434.

Müller, W. A., 1969. Auslösung der Metamorphose durch Bakterien bei den Larven von Hydractinia echinata. - Zool. Jb. (Anat. Ontogenie Tiere) 86, 84-9.5.

Müller, W. A., 1973a. Induction of metamorphosis by bacteria and ions in the planulae of Hydractinia echinata; an approach to the mode of action. - Publs Seto mar. biol. Lab. 20, 195-208.

Müller, W. A., 1973b. Metamorphose-Induktion bei Planulalarven 1. Der bakterielle Induktor. Wilhelm Roux Arch. EntwMech. Org. 173, 107-121.

Müller, W. A. \& Buchal, G., 1973. Metamorphose-Induktion bei Planulalarven II. Induktion durch monovalente Kationen: die Bedeutung des Gibbs-Donnan-Verhältnisses und der $\mathrm{Na}^{+} / \mathrm{K}^{+}$ATPase. - Wilhelm Roux Arch, EntwMech. Org. 173, 122-135.

Müller, W. A., Wieker, F. \& Eiben, R., 1976. Larval adhesion, releasing stimuli and metamorphosis. In: Coelenterate ecology and behavior. Ed. by G. O. Mackie. Plenum Press, New York, 339-346.

Neumann, R., 1976. Auslösung der Polypenmorphogenese und Kontrolle der polaren Organisation bei vegetativen Schwimmknospen von Cassiopea andromeda (Coelenterata: Scyphozoa). Dipl.Arb., Univ. Köln, 21-53.

Neumann, R., 1979. Bacterial induction of settlement and metamorphosis in the planula larvae of Cassiopea andromeda (Cnidaria: Scyphozoa, Rhizostomeae). - Mar. Ecol. Prog. Ser. 1, 21-28.

Neumann, R., 1980. Bakterielle Metamorphoseauslösung und Kontrolle der Morphogenese bei Schwimmknospen und Planulalarven von Cassiopea andromeda (Cnidaria: Scyphozoa). Diss., Univ. Köln, 16-48.

Neumann, R., Schmahl, G. \& Hofmann, D. K., 1980. Bud formation and control of polyp morphogenesis in Cassiopea andromeda (Scyphozoa). In: Developmental and cellular biology of coelenterates. Ed. P. Tardent \& R. Tardent. Elsevier, Amsterdam, 217-223.

Nishihira, M., 1966. Brief experiments on the effect of algal extracts in promoting settlement of the larvae of Coryne uchidai Stechow (Hydrozoa). - Bull. mar. biol. Stn Asamushi 13, 91-101.

Schmahl, G., 1985. Bacterially induced stolon settlement in the scyphopolyp of Aurelia aurita (Cnidaria: Scyphozoa). - Helgoländer Meeresunters. 39, 33-42.

Shaw, N., 1968. The detection of lipids on thinlayer chromatograms with the periodate-Schiff reagents. - Biochim. biophys. Acta 164, 435-436.

Wittmann, W., 1977. Auslösung der Metamorphose bei Hydractinia durch Bakterien: Isolierung und Charakterisierung der Bakterien und der auslösenden Substanz. Diss., TU Braunschweig, 54 pp. 